\title{
DETRIMENTAL EFFECTS OF COMMONLY USED INSECTICIDES IN OIL PALM TO POLLINATING WEEVIL, Elaeidobius kamerunicus FAUST. (Coleoptera: Curculionidae)
}

\section{NOOR FAREHAN ISMAIL*; IDRIS ABD GHANI** and NURUL WAHIDA OTHMAN*}

\begin{abstract}
Elaeidobius kamerunicus is the main insect pollinator of oil palm in Malaysia. It has improved oil palm pollination, thus leading to a better yield. The lethal concentrations $\left(L C_{50}\right)$ of four currently used oil palm commercial insecticides, namely cypermethrin, trichlorfon, fipronil and Bacillus thuringiensis on E. kamerunicus were determined using residual film, topical spray and oral bioassays. The weevil mortality was recorded at 24, 48 and $72 \mathrm{hr}$ after treatment. Probit analysis was used to determine $L C_{50}$. The result showed that male weevils were more susceptible to trichlorfon and fipronil than female weevils. However, there was no difference between sexes in terms of susceptibility towards cypermethrin. Among the tested insecticides, fipronil had higher lethality on weevil whereas B. thuringiensis was less harmful to weevil mortality by $<20 \%$ even when treated at the highest concentration ( $0.26 \%$ product). Regardless of the type of insecticides and exposure time, the weevil was less sensitive to the insecticide applied via spray method as compared to oral and residual film. The study findings provide useful information in determining the less harmful insecticides to this pollinating weevils with various mode of actions.
\end{abstract}

Keywords: Elaeidobius kamerunicus, oil palm, insect pollinator, insecticides.

Date received: 23 April 2019; Sent for revision: 24 May 2019; Accepted: 8 October 2019; Available online: 27 August 2020.

\section{INTRODUCTION}

Elaeidobius kamerunicus (Faust.) is the main pollinator in the oil palm plantations in Malaysia. It is an exotic insect, which was imported from Cameroon, West Africa to improve the oil palm pollination efficiency in Malaysia (Syed et al., 1982). It was first released

\footnotetext{
Department of Biological Sciences and Biotechnology,

Faculty of Science \& Technology,

Universiti Kebangsaan Malaysia,

43600 Bangi, Selangor, Malaysia.

E-mail:wahida@ukm.edu.my

** Publication Enhancement Unit, Level 5, Chancellor Building,

Universiti Kebangsaan Malaysia,

43600 Bangi, Selangor, Malaysia.
}

to the oil palm plantation in Pamol and Mamor, Kluang, Johor, Malaysia in 1981 and the following year its population had spread over to most of oil palm plantations in Peninsular Malaysia (Basri et al., 1983). Prior to that, Thrips hawaiiensis (Morgan) was the main pollinating agent in oil palm plantations but it was less efficient than the weevil (Syed, 1979). Besides, hand pollination was also used by most growers, especially for the young palms (Hussein and Rahman, 1991).

Elaeidobius kamerunicus has left huge impact on the Malaysian oil palm industry and economy (Chiu, 1984). The yield increased from $48 \%-52 \%$ to $62.3 \%-89.6 \%$ after the weevil was introduced (Syed et al., 1982; Basri et al., 1987). Besides, a million dollar was saved through cessation of hand-assisted 
pollination (Chiu, 1984; Kevan et al., 1986). These contribute to the increase in Malaysian revenue, making Malaysia as the second highest global oil palm producer and exporter (Chiu, 1984; Ferdous Alam et al., 2015; Kushairi, 2019). Therefore, the weevil is known as the multimillion dollar weevil (Greathead, 1983).

However, the reduction in oil extraction rate (OER) over the last four years become a major concern among the oil palm growers in Malaysia (BEPI, 2018). One of the possible factors resulting in the decline in OER is the reduction in the yield and quality of fruit (Donough et al., 1996; Rao and Law, 1998). According to Lawton (1982), the reduction in the number of fruit set is probably caused by poorer pollination, which is associated with E. kamerunicus effectiveness as the oil palm pollinator.

The E. kamerunicus activities and population is affected by weather and its natural enemies (Syed and Saleh, 1988; Sugih et al., 1996; Poinar et al., 2002; Ponnamma et al., 2006). In addition, the extensive use of pesticides to control oil palm pest can leave negative impact on weevil population and pollination activity (Rosma Hasibuan et al., 2002; Kalidas et al., 2008; Kok et al., 2010; Yudayati and Hamid, 2015; Prasetyo et al., 2018; Wahyu Syahputra et al., 2018). Although several studies on the lethality effect of insecticides used in oil palm against the pollinating weevil have been reported, there is still lack of information about the susceptibility of this weevil to insecticides especially in determining the insecticides median lethal concentration $\left(\mathrm{LC}_{50}\right)$ of the weevil. In fact, the determination of the $\mathrm{LC}_{50}$ value will help to examine the relationship between dose/concentration response and animal mortality (Chandra et al., 2014). The smaller the $\mathrm{LC}_{50}$ value, the more toxic is the insecticide to the animal. Besides, the $\mathrm{LC}_{50}$ value is also used to evaluate the lethality of a particular insect species in response to diverse insecticides mode of actions under similar test condition (Paramasivam and Selvi, 2017). The value serves as a basic data to label insecticides and can be used in sub-chronic and chronic studies. Therefore, the aims of this study were to determine the $\mathrm{LC}_{50}$ of insecticides commonly used in oil palm plantations and to evaluate their lethality and efficacy on E. kamerunicus.

\section{MATERIAL AND METHODS}

\section{Insects}

All E. kamerunicus used in bioassays came from the post-anthesis stage of oil palm male inflorescences. The samples were collected from the Malaysian Palm Oil Board (MPOB) plantation in Keratong, Pahang, Malaysia. This site was choosen due to its insecticide-free status as there was no incident of insect pest outbreak in this area besides the rodent issue. Thus, the E. kamerunicus samples collected in this experiment were more credible and assumed to not have any resistance developed towards the insecticides that would be tested on them. The collected spikelets were kept in rearing cage (16 cm in height and $10 \mathrm{~cm}$ in diameter) and maintained in the Centre for Insect Systematic (CIS), Universiti Kebangsaan Malaysia (UKM), Selangor under room temperature and relative humidity of 60\%-80\% with 12L:12D photoperiod. The emerging adult weevils were sexed by examining according to the length of their snout, body size and the presence of setae on the edge of elytra. The male weevils have shorter snout and larger body size than females. The presence of setae on the edge of elytra indicates male weevil. Male and female weevils were then transferred into new rearing cage separately. The freshly anthesised oil palm male inflorescences free from E. kamerunicus were used as the food source for the weevils. All E. kamerunicus adults used in the bioassays emerged from the inflorescences were at three days of age.

\section{Host Plant Material}

The spikelets of oil palm male inflorescence at the anthesis stage were cut with pruning scissors and stored in refrigerator at $1.93 \pm 0.27^{\circ} \mathrm{C}$ with $66.09 \% \pm 2.96$ relative humidity. At this stage, the wild E. kamerunicus can be observed on the spikelet. The wild E. kamerunicus will be dead once the spikelets were stored in the refrigerator. All the dead wild E. kamerunicus attached to the spikelets were removed once they were taken out from the refrigerator prior to the experiment. This was to avoid confusion regarding the E. kamerunicus mortality data.

\section{Insecticides}

The insecticides (treatments) used in the bioassays were 5.5\% cypermethrin EC, $95 \%$ trichlorfon SC, $80 \%$ fipronil WG and Bacillus thuringiensis subsp. Kurstaski ES. Distilled water was used as control.

\section{Bioassay Methods}

The residual film, topical spray and oral (feeding) were used as the bioassay methods. Bioassays were conducted in the UKM insect laboratory at room temperature and relative humidity of $60 \%$ $80 \%$ with 12L:12D photoperiod. To determine the LC, a preliminary study was performed to find the concentration range of the insecticides against the weevils. Each insecticide was tested using a serial dilution where distilled water was used as the solvent. Half of the recommended label rate for field application was used as a starting solution in the serial 
dilution except for $B$. thuringiensis $(\mathrm{Bt})$ where the full field rate $(0.26 \%$ product) was used. In the test, each of the tested insecticide has different concentration range due to different insecticide has different recommended label rate for field application.

Residual film. Insecticide-diluted solutions were applied inside the glass jar surface $(9 \mathrm{~cm}$ in height by $5 \mathrm{~cm}$ diameter). Distilled water was used as control. To get a uniform coverage throughout the jar surface, $250 \mu$ l diluted solution was inserted using micropipette and the jar was then manually rotated until all the surface was covered with the solution. The jar was left to dry in fume hood for $12 \mathrm{hr}$ before the weevils were released into it. Ten randomly selected three-day old male weevils were placed in each jar. The glass jar was then covered with organza to allow ventilation, and secured with a rubber band at the mouth ring to prevent the weevils from escaping. The weevils were fed with untreated male inflorescense at the anthesis stage $(2 \mathrm{~cm}$ in length) which was held at the centre of the cloth covering the glass jar. The weevils were deemed dead if they did not react when their legs were touched with the paint brush. Similar procedure was conducted on female weevils. Each treatment including control was replicated four times. The number of dead $E$. kamerunicus was recorded at 24, 48 and $72 \mathrm{hr}$ after treatment. The experiment was arranged following complete randomised design (CRD). Residual test was conducted according to the method of Desneux et al. (2006) with modification.

Topical spray. Ten randomly selected three-day old male weevils were put into plastic cup (200 ml) before being sprayed with $3 \mathrm{ml}$ insecticides using a handheld sprayer. The weevils were removed from treated area right after spraying and transferred into new, insecticide-free plastic cup. The amount of spray applied on each adult weevil was not determined. An insecticide-free spikelet of oil palm anthesising male was put into the cup as the weevil food source. The weevils were deemed dead if they did not react when their legs touched the paint brush. Similar procedure was repeated on female weevils. Each treatment was replicated four times following CRD experimentals design. The number of dead E. kamerunicus was recorded at 24, 48 and $72 \mathrm{hr}$ after treatment. Topical spraying test was conducted according to the method of Kaakeh (2006) with modification.

Oral (feeding). Ten randomly selected three-day old male weevils were starved for $24 \mathrm{hr}$ before being introduced with treated spikelet into the testing area (using plastic cup as mentioned above). An anthesising male spikelet was used as the weevil food source. The spikelet was dipped for $60 \mathrm{~s}$ in the insecticide solutions or distilled water (control) and allowed to dry up for $4 \mathrm{hr}$ in the fume chamber. Later, the treated spikelet was transferred inside a plastic cup $(200 \mathrm{ml})$ containing starved male weevils. The weevils were deemed dead if they did not react when their legs touched the paint brush. Similar procedures was conducted on female weevils. Each treatment was replicated four times following CRD design. The number of dead E. kamerunicus was recorded at 24, 48 and $72 \mathrm{hr}$ after treatment. Oral method was conducted following bolt-dip method by Carrillo et al. (2013) with modification.

\section{Data Analysis}

The number of dead E. kamerunicus was corrected according to Abbot (1925) prior to analysis. The $\mathrm{LC}_{50}$ was determined using Probit analysis in the PoloPlus software. The significant difference between the $\mathrm{LC}_{50}$ values is demonstrated when the $95 \%$ confidence limits (CL) between treatments do not overlap with each other. Meanwhile, the data of weevil mortality in percentage was based on concentration-dependent fashion that was analysed using two-way analysis of variance (ANOVA) (sex and concentration as the variables). When ANOVA result was significant $(p<0.05)$, Tukey test was used to separate the treatment means. However, the data needed to be normalised using $\operatorname{arsin} \sqrt{ } \chi$ transformation prior to two-way ANOVA. The mortality data of $E$. kamerunicus treated with various Bt concentrations were analysed with Kruskal-Wallis test due to nonnormal data distribution. All ANOVA and KruskalWallis tests were done using the Minitab Software version 17 (Minitab Inc.).

\section{RESULTS}

From the Probit analysis, the estimated $\mathrm{LC}_{50}$ values with $95 \% \mathrm{CL}$ and the slope of regression lines are presented in Table 1. Regardless of the methods used and exposure time, the $\mathrm{LC}_{50}$ values of male and female weevils were not significantly different when treated with cypermethrin, which is denoted by the overlapping of $95 \% \mathrm{CL}$ of the $\mathrm{LC}_{50}$ values. In contrast, the susceptibility of male and female weevils towards trichlorfon at different exposure times showed no overlapping of the $\mathrm{LC}_{50} 95 \% \mathrm{CL}$. The $\mathrm{LC}_{50}$ value of trichlorfon tested on female weevil $\left(\mathrm{LC}_{50}=27.56\right.$ ppm) in residual method was significantly higher than male $\left(\mathrm{LC}_{50}=13.57 \mathrm{ppm}\right)$ after $24 \mathrm{hr}$ treatment whereas in the spray and oral methods, the $\mathrm{LC}_{50}$ values of trichlorfon for male weevils (spray: $\mathrm{LC}_{50}=$ 192.11 ppm; oral: $L_{50}=$ ppm 9.80) were significantly lower than females (spray: $\mathrm{LC}_{50}=356.21 \mathrm{ppm}$; oral: $\left.\mathrm{LC}_{50}=11.66 \mathrm{ppm}\right)$ after $72 \mathrm{hr}$ treatment. Irrespective of exposure time, there was no difference in $\mathrm{LC}_{50}$ values of fipronil for male and female weevils in residual method. However, the $\mathrm{LC}_{50}$ values of fipronil for males were significantly lower than for females 
in spray and oral methods. There were no $\mathrm{LC}_{50}$ values for orally Bt-treated weevils because even at the highest concentration of Bt (recommended field concentration) their mortality was $<20 \%$.

In terms of insecticide toxicity effect in all bioassays on male E. kamerunicus, it was shown that fipronil had the lowest $\mathrm{LC}_{50}$ values followed by cypermethrin and trichlorfon across the exposure times. Similar results were obtained for female weevils, where fipronil showed the lowest $\mathrm{LC}_{50}$ values as compared to cypermethrin and trichlorfon. Therefore, the results suggested that fipronil and trichlorfon had the highest and lowest acute toxicity on E. kamerunicus, respectively.

TABLE 1. LETHAL CONCENTRATION (LC ${ }_{50}$ ) OF THREE INSECTICIDES ON . kamerunicus AFTER EXPOSED TO INSECTIDES AT 24, 48 AND $72 \mathrm{hr}$ BY THREE DIFFERENT BIOASSAY METHODS

\begin{tabular}{|c|c|c|c|c|c|c|}
\hline \multirow{2}{*}{ Insecticide } & \multirow{2}{*}{ Sex } & \multirow{2}{*}{ Method } & & \multicolumn{3}{|c|}{ Hour after treatment (HAT) } \\
\hline & & & & 24 & 48 & 72 \\
\hline \multirow[t]{24}{*}{ Cypermethrin } & $\delta$ & Residual & $\mathrm{LC}_{50}$ & 0.85 & 0.59 & 0.36 \\
\hline & & & $95 \% \mathrm{CL}$ & $0.70-1.03$ & $0.49-0.72$ & $0.29-0.44$ \\
\hline & & & Slope \pm SE & $2.39 \pm 0.24$ & $2.28 \pm 0.22$ & $2.22 \pm 0.24$ \\
\hline & & & $\chi^{2}\left(\mathrm{dk}, \chi_{\mathrm{t}}\right)$ & $1.84(5,11.07)$ & $4.08(5,11.07)$ & $3.46(4,9.49)$ \\
\hline & 우 & Residual & $\mathrm{LC}_{50}$ & 1.14 & 0.67 & 0.44 \\
\hline & & & $95 \% \mathrm{CL}$ & $0.88-1.52$ & $0.50-0.87$ & $0.34-0.56$ \\
\hline & & & Slope \pm SE & $1.68 \pm 0.20$ & $1.80 \pm 0.20$ & $2.17 \pm 0.27$ \\
\hline & & & $\chi^{2}\left(\mathrm{dk}, \chi_{\mathrm{t}}\right)$ & $3.87(5,11.07)$ & $4.66(5,11.07)$ & $3.98(4,9.49)$ \\
\hline & 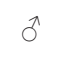 & Spray & $\mathrm{LC}_{50}$ & 1.40 & 1.11 & 1.00 \\
\hline & & & $95 \% \mathrm{CL}$ & $1.19-1.64$ & $0.91-1.33$ & $0.79-1.22$ \\
\hline & & & Slope \pm SE & $3.49 \pm 0.42$ & $2.84 \pm 0.36$ & $3.05 \pm 0.44$ \\
\hline & & & $\chi^{2}\left(\mathrm{dk}, \chi_{\mathrm{t}}\right)$ & $2.32(3,7.82)$ & $2.93(3,7.82)$ & $2.82(3,7.82)$ \\
\hline & q & Spray & $\mathrm{LC}_{50}$ & 1.49 & 1.31 & 1.19 \\
\hline & & & $95 \% \mathrm{CL}$ & $1.15-1.87$ & $0.97-1.69$ & $0.84-1.57$ \\
\hline & & & Slope \pm SE & $1.96 \pm 0.26$ & $1.76 \pm 0.25$ & $1.62 \pm 0.25$ \\
\hline & & & $\chi^{2}\left(\mathrm{dk}, \chi_{\mathrm{t}}\right)$ & $2.74(3,7.82)$ & $1.52(3,7.82)$ & $1.47(3,7.82)$ \\
\hline & $\hat{\sigma}$ & Oral & $\mathrm{LC}_{50}$ & 0.24 & 0.07 & 0.05 \\
\hline & & & $95 \%$ CL & $0.16-0.33$ & $0.04-0.10$ & $0.03-0.07$ \\
\hline & & & Slope \pm SE & $1.73 \pm 0.28$ & $2.19 \pm 0.34$ & $2.11 \pm 0.36$ \\
\hline & & & $\chi^{2}\left(\mathrm{dk}, \chi_{\mathrm{t}}\right)$ & $3.98(5,11.07)$ & $4.87(5,11.07)$ & $1.31(4,9.49)$ \\
\hline & q & Oral & $\mathrm{LC}_{50}$ & 0.21 & 0.06 & 0.03 \\
\hline & & & $95 \% \mathrm{CL}$ & $0.17-0.26$ & $0.05-0.08$ & $0.02-0.04$ \\
\hline & & & Slope \pm SE & $2.17 \pm 0.22$ & $1.92 \pm 0.20$ & $1.86 \pm 0.26$ \\
\hline & & & $\chi^{2}\left(\mathrm{dk}, \chi_{\mathrm{t}}\right)$ & $4.58(5,11.07)$ & $4.24(5,11.07)$ & $2.57(4,9.49)$ \\
\hline \multirow[t]{12}{*}{ Trichlorfon } & $\hat{\sigma}$ & Residual & $\mathrm{LC}_{50}$ & 13.57 & 13.90 & 10.61 \\
\hline & & & $95 \% \mathrm{CL}$ & $10.87-16.81$ & $9.27-17.60$ & $6.88-14.08$ \\
\hline & & & Slope \pm SE & $2.08 \pm 0.23$ & $3.48 \pm 0.73$ & $2.84 \pm 0.54$ \\
\hline & & & $\chi^{2}\left(\mathrm{dk}, \chi_{\mathrm{t}}\right)$ & $2.39(4,9.49)$ & $2.39(4,9.49)$ & $2.59(3,7.82)$ \\
\hline & q & Residual & $\mathrm{LC}_{50}$ & 27.56 & 14.04 & 11.78 \\
\hline & & & $95 \% \mathrm{CL}$ & $22.53-34.20$ & $11.04-17.42$ & $8.75-15.04$ \\
\hline & & & Slope \pm SE & $2.27 \pm 0.25$ & $2.48 \pm 0.30$ & $2.59 \pm 0.38$ \\
\hline & & & $\chi^{2}\left(\mathrm{dk}, \chi_{\mathrm{t}}\right)$ & $3.68(4,9.49)$ & $3.88(4,9.49)$ & $2.93(3,7.82)$ \\
\hline & $\delta$ & Spray & $\mathrm{LC}_{50}$ & 269.72 & 243.26 & 192.11 \\
\hline & & & $95 \% \mathrm{CL}$ & $230.47-316.43$ & $206.60-287.03$ & $157.42-241.76$ \\
\hline & & & Slope \pm SE & $3.39 \pm 0.41$ & $3.19 \pm 0.37$ & $2.60 \pm 0.38$ \\
\hline & & & $\chi^{2}\left(\mathrm{dk}, \chi_{\mathrm{t}}\right)$ & $2.43(3,7.82)$ & $1.61(3,7.82)$ & $1.79(2,5.99)$ \\
\hline
\end{tabular}


DETRIMENTAL EFFECTS OF COMMONLY USED INSECTICIDES IN OIL PALM TO POLLINATING WEEVIL, Elaeidobius kamerunicus FAUST. (Coleoptera: Curculionidae)

TABLE 1. LETHAL CONCENTRATION (LC ${ }_{50}$ ) OF THREE INSECTICIDES ON E. kamerunicus AFTER EXPOSED TO INSECTIDES AT 24, 48 AND 72 hr BY THREE DIFFERENT BIOASSAY METHODS (continued)

\begin{tabular}{|c|c|c|c|c|c|c|}
\hline \multirow{2}{*}{ Insecticide } & \multirow{2}{*}{ Sex } & \multirow{2}{*}{ Method } & & \multicolumn{3}{|c|}{ Hour after treatment (HAT) } \\
\hline & & & & 24 & 48 & 72 \\
\hline \multirow[t]{12}{*}{ Trichlorfon } & $q$ & Spray & $\mathrm{LC}_{50}$ & 359.01 & 352.18 & 356.21 \\
\hline & & & $95 \% \mathrm{CL}$ & $289.56-469.97$ & $280.36-470.57$ & 261.66-612.42 \\
\hline & & & Slope \pm SE & $2.22 \pm 0.31$ & $2.05 \pm 0.30$ & $1.91 \pm 0.37$ \\
\hline & & & $\chi^{2}\left(\mathrm{dk}, \chi_{\mathrm{t}}\right)$ & $1.617(3,7.815)$ & $2.325(3,7.815)$ & $1.11(2,5.99)$ \\
\hline & 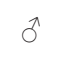 & Oral & $\mathrm{LC}_{50}$ & 20.77 & 11.91 & 9.80 \\
\hline & & & $95 \% \mathrm{CL}$ & $17.84-23.88$ & $9.83-14.00$ & $7.90-11.56$ \\
\hline & & & Slope \pm SE & $3.20 \pm 0.30$ & $3.56 \pm 0.42$ & $4.04 \pm 0.63$ \\
\hline & & & $\chi^{2}\left(\mathrm{dk}, \chi_{\mathrm{t}}\right)$ & $5.57(6,12.59)$ & $3.84(6,12.59)$ & $3.87(5,11.07)$ \\
\hline & q & Oral & $\mathrm{LC}_{50}$ & 21.87 & 16.59 & 11.66 \\
\hline & & & $95 \% \mathrm{CL}$ & $18.99-24.80$ & $14.17-18.70$ & $9.15-13.93$ \\
\hline & & & Slope \pm SE & $3.93 \pm 0.39$ & $5.03 \pm 0.64$ & $4.16 \pm 0.66$ \\
\hline & & & $\chi^{2}\left(\mathrm{dk}, \chi_{\mathrm{t}}\right)$ & $5.42(6,12.59)$ & $4.33(6,12.59)$ & $1.00(5,11.07)$ \\
\hline \multirow[t]{24}{*}{ Fipronil } & $\hat{\sigma}$ & Residual & $\mathrm{LC}_{50}$ & 0.52 & 0.14 & 0.11 \\
\hline & & & $95 \% \mathrm{CL}$ & $0.40-0.68$ & $0.11-0.16$ & $0.09-0.13$ \\
\hline & & & Slope \pm SE & $1.76 \pm 0.21$ & $2.39 \pm 0.28$ & $2.59 \pm 0.33$ \\
\hline & & & $\chi^{2}\left(\mathrm{dk}, \chi_{\mathrm{t}}\right)$ & $1.59(4,9.49)$ & $3.99(4,9.49)$ & $2.90(3,7.82)$ \\
\hline & q & Residual & $\mathrm{LC}_{50}$ & 0.47 & 0.174 & 0.10 \\
\hline & & & $95 \% \mathrm{CL}$ & $0.38-0.58$ & $0.12-0.22$ & $0.07-0.14$ \\
\hline & & & Slope \pm SE & $2.41 \pm 0.29$ & $3.04 \pm 0.51$ & $2.90 \pm 0.49$ \\
\hline & & & $\chi^{2}\left(\mathrm{dk}, \chi_{\mathrm{t}}\right)$ & $3.27(4,9.49)$ & $3.98(4,9.49)$ & $2.98(3,7.82)$ \\
\hline & 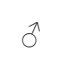 & Spray & $\mathrm{LC}_{50}$ & 0.49 & 0.30 & 0.29 \\
\hline & & & $95 \% \mathrm{CL}$ & $0.46-0.53$ & $0.26-0.34$ & $0.24-0.32$ \\
\hline & & & Slope \pm SE & $7.51 \pm 0.90$ & $5.07 \pm 0.80$ & $5.02 \pm 0.89$ \\
\hline & & & $\chi^{2}\left(\mathrm{dk}, \chi_{\mathrm{t}}\right)$ & $2.90(3,7.82)$ & $2.89(3,7.82)$ & $1.86(2,5.99)$ \\
\hline & q & Spray & $\mathrm{LC}_{50}$ & 0.90 & 0.55 & 0.47 \\
\hline & & & $95 \% \mathrm{CL}$ & $0.81-1.06$ & $0.50-0.61$ & $0.41-0.56$ \\
\hline & & & Slope \pm SE & $4.93 \pm 0.77$ & $4.96 \pm 0.60$ & $3.26 \pm 0.63$ \\
\hline & & & $\chi^{2}\left(\mathrm{dk}, \chi_{\mathrm{t}}\right)$ & $1.82(3,7.82)$ & $1.97(3,7.82)$ & $1.38(2,5.99)$ \\
\hline & $\delta$ & Oral & $\mathrm{LC}_{50}$ & 0.026 & 0.007 & 0.004 \\
\hline & & & $95 \% \mathrm{CL}$ & $0.020-0.031$ & $0.002-0.010$ & $0.000-0.008$ \\
\hline & & & Slope \pm SE & $2.70 \pm 0.37$ & $2.55 \pm 0.74$ & $1.94 \pm 0.69$ \\
\hline & & & $\chi^{2}\left(\mathrm{dk}, \chi_{\mathrm{t}}\right)$ & $3.23(5,11.07)$ & $0.80(5,11.07)$ & $0.41(4,9.49)$ \\
\hline & 우 & Oral & $\mathrm{LC}_{50}$ & 0.08 & 0.03 & 0.01 \\
\hline & & & $95 \% \mathrm{CL}$ & $0.07-0.10$ & $0.02-0.03$ & $0.01-0.02$ \\
\hline & & & Slope \pm SE & $2.74 \pm 0.28$ & $7.59 \pm 1.54$ & $3.45 \pm 0.71$ \\
\hline & & & $\chi^{2}\left(\mathrm{dk}, \chi_{\mathrm{t}}\right)$ & $4.55(5,11.07)$ & $0.01(5,11.07)$ & $3.25(4,9.49)$ \\
\hline \multirow{4}{*}{$\begin{array}{l}\text { Bacillus thuringiensis } \\
\text { subsp. Kurstaski }\end{array}$} & qर्ठ & Oral & $\mathrm{LC}_{50}$ & $*_{-}$ & - & - \\
\hline & & & $95 \% \mathrm{CL}$ & - & - & - \\
\hline & & & Slope \pm SE & - & - & - \\
\hline & & & $\chi^{2}\left(\mathrm{dk}, \chi_{\mathrm{t}}\right)$ & - & - & - \\
\hline
\end{tabular}

Note: *Analysis is not conducted due to the mortality of weevill $<50 \%$ even though treated with the higher concentration (recommended rate in field).

CL - confidence limits.

SE - standard error. 
In general, males E. kamerunicus that were exposed to insecticides by spraying method had significantly higher $\mathrm{LC}_{50}$ than those exposed to residual and oral insecticides over time. Similar results were obtained for females E. kamerunicus, where those exposed to insecticides by spray method had significantly higher $\mathrm{LC}_{50}$ value than those exposed to the respective insecticides tested by other methods.

All the calculated chi-squared $\left(\chi^{2}\right)$ values were lesser than the tabulated chi-squared $\left(\chi_{\mathrm{t}}\right)$ values, indicating the $\chi^{2}$ values are not significantly different (Table 1). In general, the slopes for male weevils were steeper than females for all methods and treatments. Regardless of the methods and sex, the $\mathrm{LC}_{50}$ slopes for weevils treated with fipronil were steeper than trichlorfon and cypermethrin. For trichlorfon, the $\mathrm{LC}_{50}$ slopes for male weevils in oral method $(4.04 \pm 0.63)$ were steeper than residual $(2.84 \pm 0.54)$ and spray $(2.59 \pm 0.38)$ methods after $72 \mathrm{hr}$ exposure while for the female weevils, the oral method slopes were steeper than those of other methods after $48 \mathrm{hr}$ and $72 \mathrm{hr}$ exposure. For fipronil, the $\mathrm{LC}_{50}$ slopes for male weevils in spray method were steeper than residual and oral methods at all exposure times. This is similar to the female weevils, where the $\mathrm{LC}_{50}$ slopes in spray method $(4.93 \pm 0.77)$ were steeper than those of residual $(2.41 \pm 0.29)$ and oral methods $(2.74 \pm 0.28)$ after $24 \mathrm{hr}$ treatment. However, after $48 \mathrm{hr}$ exposure, the $\mathrm{LC}_{50}$ slopes of female weevils in oral method (7.59 \pm 1.54$)$ were steeper than residual $(3.04 \pm 0.51)$ and spray methods $(4.96 \pm 0.60)$.

The percentage mortality of E. kamerunicus caused by insecticides is based on concentrationdependent relationship as shown in Table 2 and Figures 1 to 6 . For the residual film method, there was no significant interaction between sex and concentration as well as between the sexes alone for all the tested insecticides that cause the death of E. kamerunicus. However, each insecticide concentration was found to have a significant effect to the weevil mortality percentage (Table 2 and Figure 1). The exposure to the two highest concentrations of cypermethrin and trichlorfon caused significantly higher weevil mortality than other concentrations. Almost 90\% weevils were dead when they were in contact with the fipronil residue at the highest concentration (1.56 ppm) (Figure 1). However, the weevil mortality percentage decreases significantly after being exposed to the lower insecticide concentrations. For spray method, the interaction between sex and concentration as well as between the sexes alone had no significant effect on weevil death when they were treated with cypermethrin and trichlorfon (Table 2). Cypermethrin caused significantly higher weevil mortality at the two highest concentrations
(4.10 ppm and $8.19 \mathrm{ppm}$ ) in comparison to other concentrations. Meanwhile for trichlorfon, almost $80 \%$ weevils were dead when being exposed to the highest concentration (600 ppm) but the mortality was $<3 \%$ at the lowest concentration (50 $\mathrm{ppm}$ ) (Figure 2). In contrast, there was significant interaction between sex and concentration on the weevil mortality when they were exposed to fipronil. Besides, different concentrations and sex alone significantly affected weevil mortality (Table 2). At the concentration of $0.38 \mathrm{ppm}$ to the highest, the mortality of male weevils was significantly higher than females (Figure 3). This shows that male weevils are more susceptible to fipronil than the females. Female weevils treated with the two highest fipronil concentrations (0.77 ppm and 1.02 ppm) had significantly higher mortality than those exposed to the lowest concentration $(0.26 \mathrm{ppm})$, with mortality of only $<3 \%$. Meanwhile, the male weevils exposed to the two highest fipronil concentrations $(0.77 \mathrm{ppm}$ and $1.02 \mathrm{ppm}$ ) had highest mortality ( $>95 \%$ death) as compared to other concentrations (Figure 3). For oral method, the interaction between sex and concentration as well as between the sexes had no significant effect on weevil death when they were treated with cypermethrin and trichlorfon (Table 2). The contact with cypermetherin and trichlorfon via oral method at the two highest concentrations had resulted in significantly higher weevil mortality than the remaining concentrations (Figure 4). However, there was no difference in weevil mortality at the three lowest cypermethrin concentrations, in which the percentage of weevil death was similar to the control. There was significant interaction between sex and fipronil concentration that contributed to the weevil death (Table 2). Sex and fipronil concentration alone also significantly affected the percentage of weevil mortality. As the concentration increased, the percentage of male weevil mortality had increased significantly higher than female percentage mortality, where only $62.50 \%$ females were killed but all male weevils (100\%) were killed when exposed to the highest fipronil concentration (0.10 ppm) (Figure 5). The male E. kamerunicus orally treated with different $\mathrm{Bt}$ concentrations showed no difference in weevil mortality throughout the exposure times when analysed using Kurskal-Wallis tests [ 24 and $48 \mathrm{hr}$ after treatment (HAT), $\mathrm{H}=5.07$; $\mathrm{df}=4 ; \mathrm{P}=0.28 ; 72$ HAT, $\mathrm{H}=8.04 ; \mathrm{df}=4 ; \mathrm{P}=0.09]$. Similar results were observed for female weevils, where there was no significant difference in mortality between different $\mathrm{Bt}$ concentrations at all exposure times ( 48 and $72 \mathrm{HAT}, \mathrm{H}=5.07 ; \mathrm{df}=4 ; \mathrm{P}=0.28$ ). Except at $24 \mathrm{hr}$ after treament, the data cannot be generated due to the absence of weevil mortality when exposured to different $\mathrm{Bt}$ concentrations (Figure 6). 

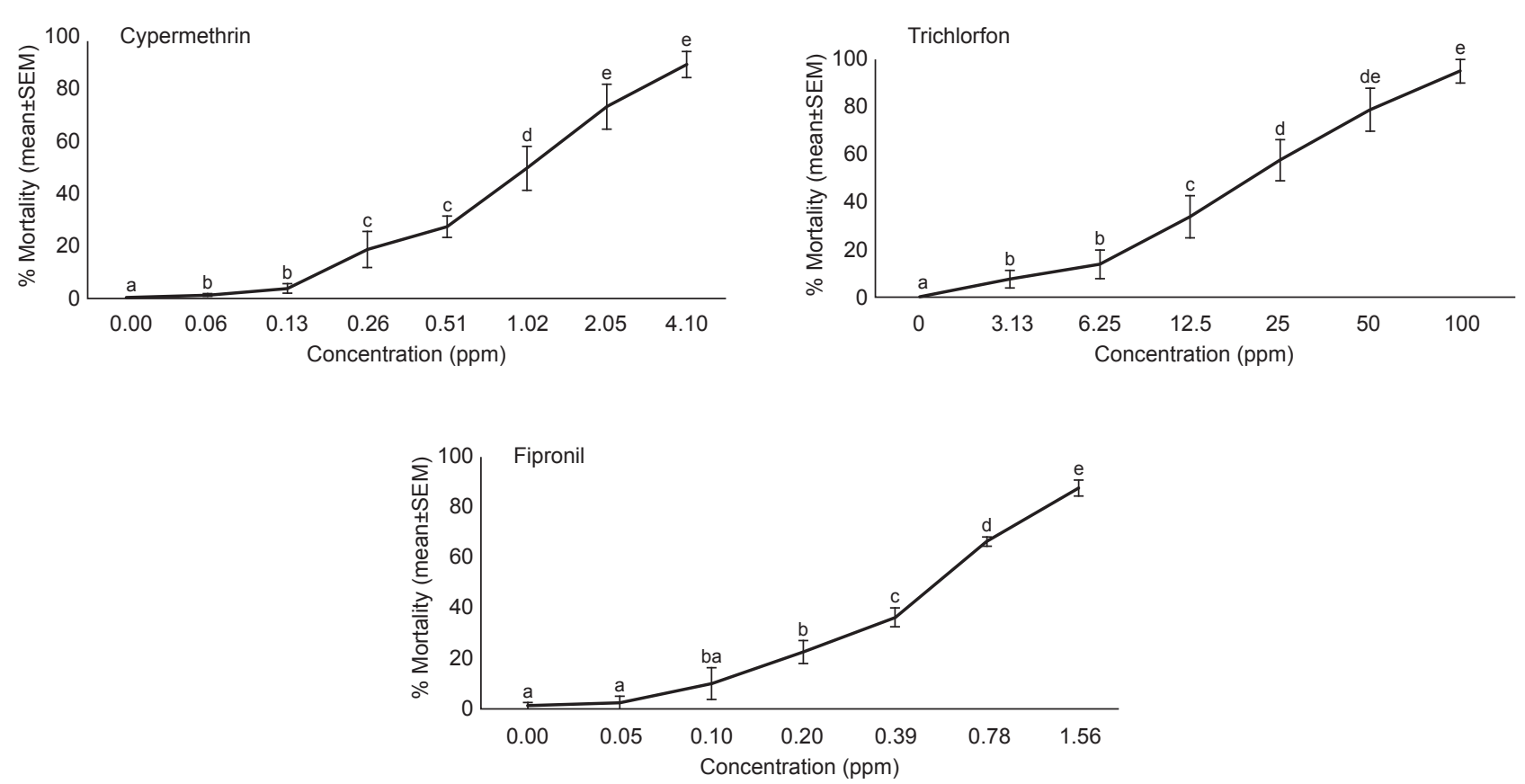

Figure 1. Percentage mortality of E. kamerunicus $24 \mathrm{hr}$ after exposure to different concentrations of selected insecticides by residual film method. The insecticide concentration ' 0 ' represents the no-insecticide control treatment. Error bars represent the scanning electron microscope (SEM).
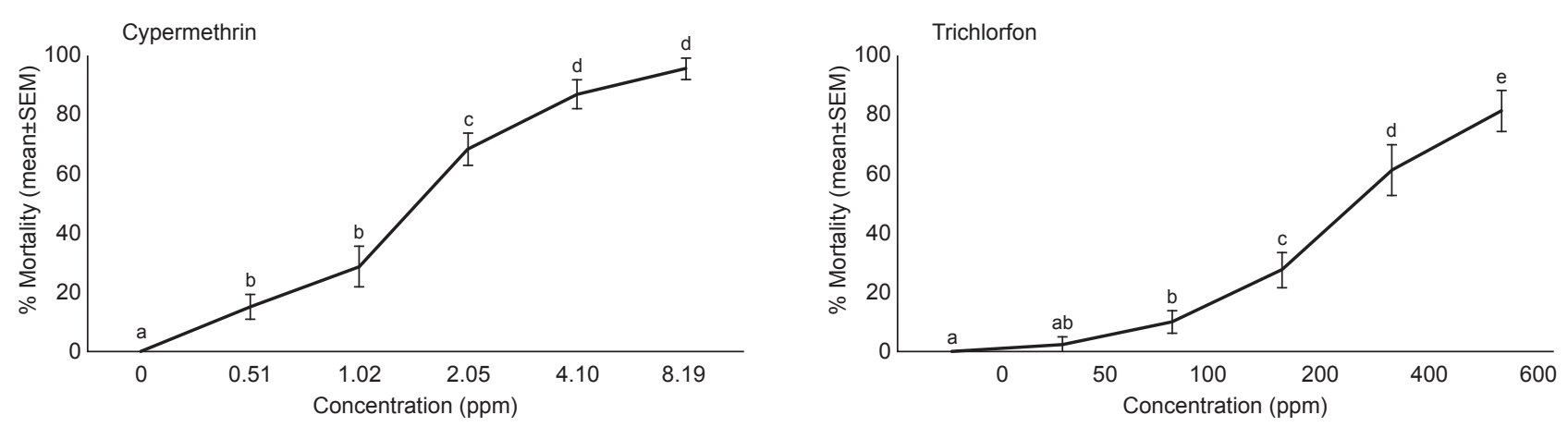

Figure 2. Percentage mortality of E. kamerunicus $24 \mathrm{hr}$ after exposure to different concentrations of cypermethrin and trichlorfon by spraying method. The insecticide concentration ' 0 ' represents the no-insecticide control treatment. Error bars represent the scanning electron microscope (SEM).

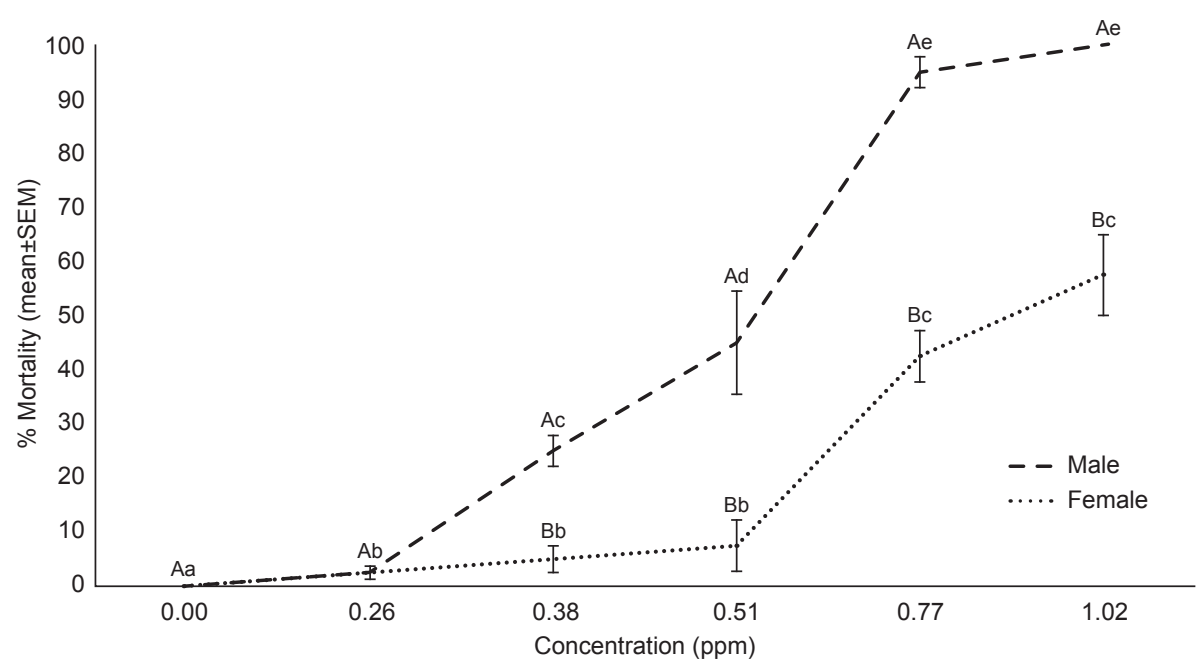

Figure 3. Percentage mortality of E. kamerunicus male and female $24 \mathrm{hr}$ after exposure to different concentrations of fipronil by spraying method. The insecticide concentration ' 0 ' represents the no-insecticide control treatment. Error bars represent the scanning electron microscope (SEM). 

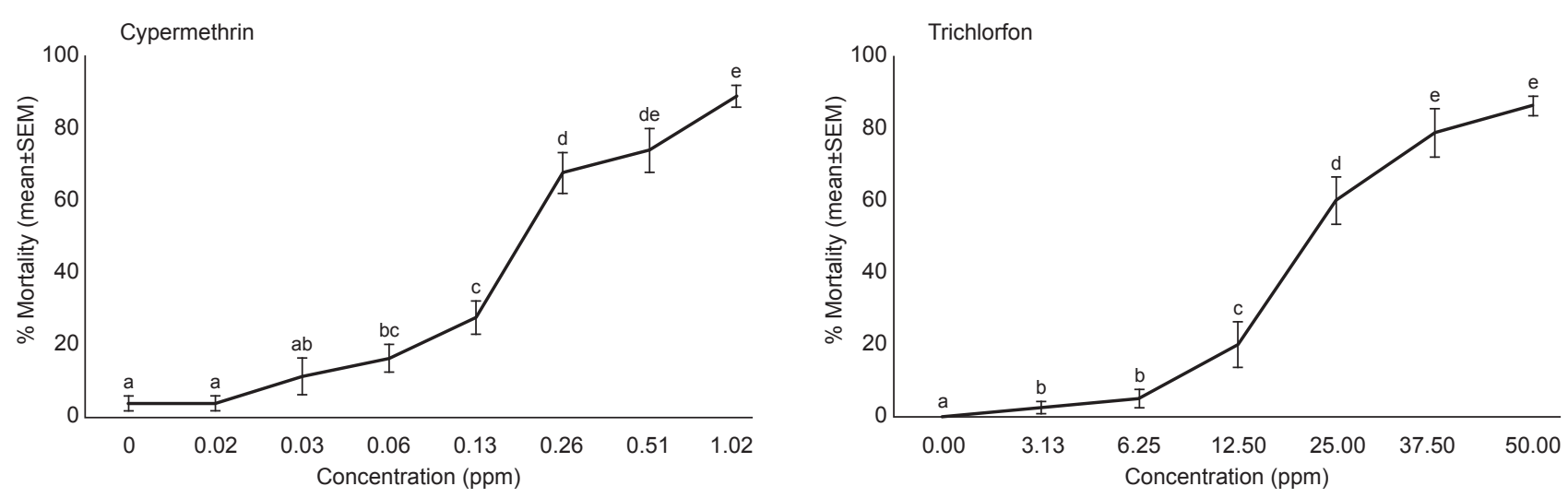

Figure 4. Percentage mortality of E. kamerunicus $24 \mathrm{hr}$ after exposure to different concentrations of cypermethrin and trichlorfon by oral method. The insecticide concentration ' 0 ' represents the no-insecticide control treatment. Error bars represent the scanning electron microscope (SEM).

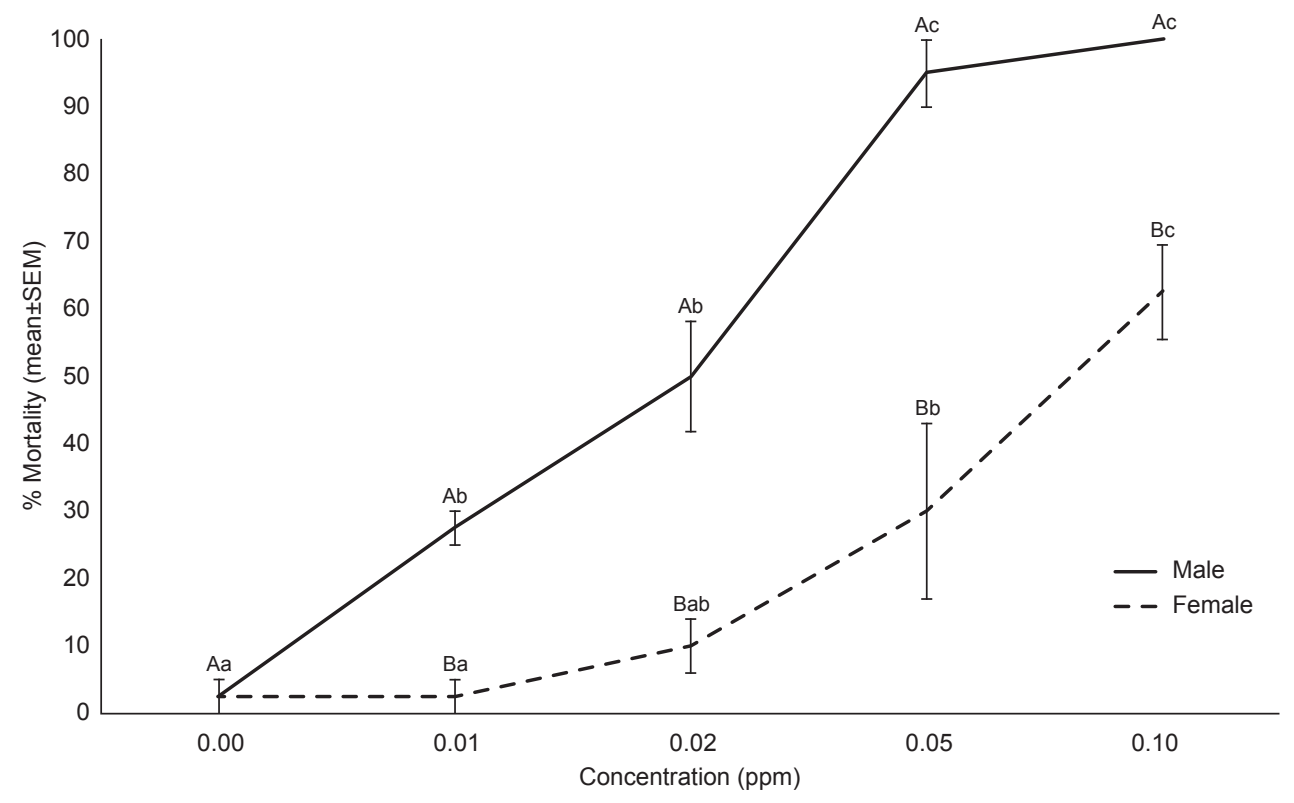

Figure 5. Percentage mortality of E. kamerunicus $24 \mathrm{hr}$ after exposure to different concentrations of fipronil by oral method. The insecticide concentration ' 0 ' represents the no-insecticide control treatment. Error bars represent the scanning electron microscope (SEM).
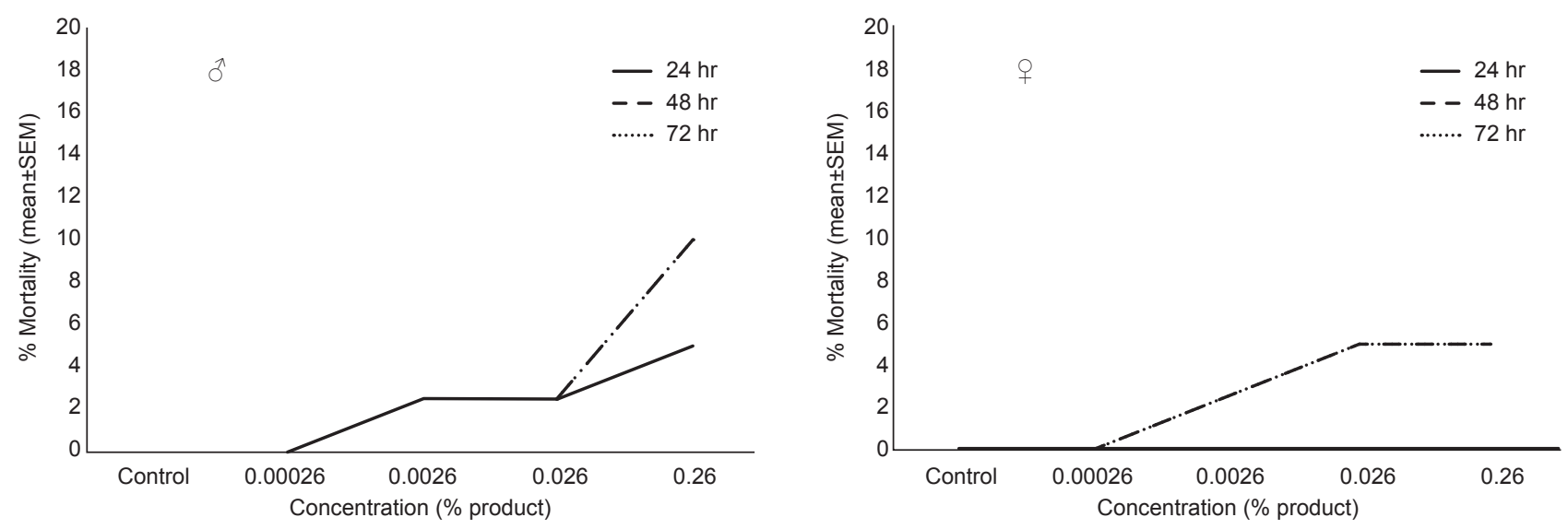

Figure 6. Percentage mortality of E. kamerunicus when treated with Bacillus thuringiensis subsp. Kurstaski by oral bioassay. 
DETRIMENTAL EFFECTS OF COMMONLY USED INSECTICIDES IN OIL PALM TO POLLINATING WEEVIL, Elaeidobius kamerunicus FAUST. (Coleoptera: Curculionidae)

TABLE 2. ANALYSIS OF VARIANCE (ANOVA) STATISTICS FOR THE EFFECT OF SELECTED INSECTICIDES ON E. kamerunicus MORTALITY PERCENTAGE AT 24 hr AFTER EXPOSURE

\begin{tabular}{|c|c|c|c|c|c|c|c|}
\hline Method & Chemicals & Sources & DF & SS & MS & F-value & P-value \\
\hline \multirow[t]{12}{*}{ Residual } & Cypermethirn & Sex & 1 & 279.90 & 279.90 & 1.72 & 0.20 \\
\hline & & Concentration & 7 & 47047.80 & 6721.10 & 41.34 & 0.00 \\
\hline & & Interaction & 7 & 774.40 & 110.70 & 0.68 & 0.69 \\
\hline & & Error & 48 & 7804.70 & 162.60 & - & - \\
\hline & Trichlorfon & Sex & 1 & 2357 & 2357 & 2.28 & 0.14 \\
\hline & & Concentration & 6 & 45619.00 & 7603.20 & 34.81 & 0.00 \\
\hline & & Interaction & 6 & 1140.70 & 190.10 & 0.87 & 0.53 \\
\hline & & Error & 42 & 9173.40 & 218.40 & - & - \\
\hline & Fipronil & Sex & 1 & 44.6 & 44.60 & 0.38 & 0.54 \\
\hline & & Concentration & 6 & 53285.70 & 8881.00 & 75.74 & 0.00 \\
\hline & & Interaction & 6 & 342.90 & 342.90 & 0.49 & 0.81 \\
\hline & & Error & 42 & 4925.00 & 117.30 & - & - \\
\hline \multirow[t]{12}{*}{ Spray } & Cypermethirn & Sex & 1 & 52.10 & 52.10 & 0.29 & 0.59 \\
\hline & & Concentration & 5 & 64568.80 & 12913.80 & 72.92 & 0.00 \\
\hline & & Interaction & 5 & 1085 & 217.10 & 1.23 & 0.32 \\
\hline & & Error & 36 & 6375 & 177.10 & - & - \\
\hline & Trichlorfon & Sex & 1 & 118.70 & 118.70 & 0.73 & 0.40 \\
\hline & & Concentration & 5 & 29588.10 & 5917.60 & 36.58 & 0.00 \\
\hline & & Interaction & 5 & 1015.40 & 203.10 & 1.26 & 0.30 \\
\hline & & Error & 36 & 5823.70 & 161.80 & - & - \\
\hline & Fipronil & Sex & 1 & 7752.10 & 7752.10 & 93.81 & 0.00 \\
\hline & & Concentration & 5 & 46018.80 & 9203.80 & 111.37 & 0.00 \\
\hline & & Interaction & 5 & 4985.40 & 997.10 & 12.07 & 0.00 \\
\hline & & Error & 36 & 2975.00 & 82.60 & - & - \\
\hline \multirow[t]{12}{*}{ Oral } & Cypermethirn & Sex & 1 & 394.90 & 394.94 & 0.57 & 0.45 \\
\hline & & Concentration & 7 & 37129.00 & 5304.14 & 55.76 & 0.00 \\
\hline & & Interaction & 7 & 1244.00 & 177.72 & 1.87 & 0.10 \\
\hline & & Error & 48 & 4565.70 & 95.12 & - & - \\
\hline & Trichlorfon & Sex & 1 & 0.60 & 0.60 & 0.01 & 0.94 \\
\hline & & Concentration & 6 & 41399.10 & 6899.80 & 72.52 & 0.00 \\
\hline & & Interaction & 6 & 702.00 & 117.00 & 1.23 & 0.31 \\
\hline & & Error & 42 & 3995.90 & 95.10 & - & - \\
\hline & Fipronil & Sex & 1 & 23715.20 & 5928.81 & 40.72 & 0.00 \\
\hline & & Concentration & 4 & 8935.80 & 8935.80 & 61.37 & 0.00 \\
\hline & & Interaction & 4 & 3075.30 & 768.81 & 5.28 & 0.00 \\
\hline & & Error & 30 & 4368.20 & 145.61 & - & - \\
\hline
\end{tabular}

Note: DF - degree of freedom; SS - sum of squares; MS - mean square.

\section{DISCUSSION}

Oil palm is a monoculture crop that provides habitat for a number of plant-eating insect pests such as lepidopteran pest (i.e. bagworms, nettle caterpillars and bunch moth), termite and beetle (i.e. Oryctes rhinoceros) due to the abundant and sustainable food sources. Hence, to prevent from the loss of yield, oil palm plantation has implemented an integrated pest management (IPM) practise to address the issue (Kuntom et al., 2007). Implementation of IPM in agroecosystem helps in reducing the usage of insecticides through the increase of natural enemies. Although there are natural enemies to control the oil palm insect pests, their population is insufficient for effective control especially during the insect pest outbreak (Young, 1971). Thus, insecticides become the main tool in reducing the insect pest population during the outbreak. Most of the planters use broad spectrum insecticides (e.g. cypermethrin, trichlorofon and fipronil) due to the presence of different insect herbivoures species in oil palm 
plantation. Furthermore, cheaper in price, easily accessible, low cost to operate and fast result make these insecticides the main choice among planters (Norman, 1994; Kuntom et al., 2007). However, overdosing and frequent use of insecticides as preventive applications can lead to adverse effects on human health and also can lead to environmental pollution (Basiron, 2007; RSPO, 2013). Besides, some insects have developed physiological and behaviour resistance to insecticide (Martínez et al., 2009). In addition, excessive use of insecticide also can give harmful effect to the beneficial organisms such as natural enemies and the oil palm pollinators. Therefore, the impact of insecticides that are commonly used in oil palm plantation either directly or indirectly on E. kamerunicus need to be evaluated as this weevil plays a major role in oil palm pollination.

The study results showed that female weevils are less susceptible to insecticides than males (Table 1, Figures 3 and 5). This is consistent with the previous studies on several insect species (Rathman et al., 1992; Weaver et al., 1994; Shearer and Usmani, 2001; Noor Farehan et al., 2013). There are factors that lead to differences in terms of susceptibility towards insecticides between sexes, size and metabolism (Rathman et al.,1992; Weaver et al.,1994; Tillman, 1995). The bigger the size, the higher is the tolerance to insecticide (Abdelrahmen, 1973; Scott and Rutz, 1988; Rathman et al., 1992; Weaver et al., 1994; Shearer and Usmani, 2001; Noor Farehan et al., 2013). In fact, the insects with larger body size have higher amount of lipid that helps them to be more tolerant to insecticides (Munson and Gottlied, 1953; Roy and Prasad, 2018). Lipid is one of the molecules stored in body fat that is involved in synthesising detoxification enzymes; it can reduce the effect of insecticides on the insects (Terriere, 1982; Roy and Prasad, 2018). Interestingly, female E. kamerunicus has smaller body size than males. One of the reasons the female E. kamerunicus are more tolerant to insecticides is due to vitellogenesis. Vitellogenesis is the process of yolk formation, which occurs during egg development (Telfer, 2009). This process is important as it provides nutrients for embryo development in the insects (Valle, 1993). According to Telfer (2009), during egg production, the female body fat secretes proteins that will be used during vitellogenesis. Despite having smaller body size than males, the female weevils still have higher amount of lipid as they need fat to produce eggs. Another reason for the different susceptibility towards insecticides is that the detoxification activity of the female weevils is higher than males. Based on the study done by De Lame et al. (2001) on the Oriental fruit moth, Grapholita molesta, even though the females have larger body size, it was found that the male moths are more tolerant to organophosphate (OP) than females due to differences in the level of degrading acetylcholinesterase (AChE) enzyme and insensitivity enzyme AChE to OP, making the female moths to be more susceptible. However, further study needs to be conducted to prove this assumption on E. kamerunicus.

Both male and female E. kamerunicus treated with fipronil had lower $\mathrm{LC}_{50}$ values as compared to the weevils treated with cypermethrin and trichlorfon (Table 1). The lower susceptibility of E. kamerunicus towards cypermethrin and trichlorfon could be due to the weevils having already developed resistance to both insecticides, since both are being widely used to control oil palm leaf defoliator insect pests such as bagworms and nettle caterpillars (Wood, 1968; Chung, 1989; Norman and Basri, 1992; Kuntom et al., 2007, Kok et al., 2012). Besides that, although all these insecticides are classified under neurotoxic group but the differences in mode of actions or targeted site of action in the nervous system could contribute to difference degree of toxicity effect on $E$. kamerunicus. The mode of action of fipronil involves the blocking of $\gamma$-aminobutryric acid (GABA)-gated chloride channel, thus leading to hyperexcitation at lower dose, as well as paralysis and death at higher dose (Cole et al., 1993; Brooks, 2010; Gupta and Milatovic, 2014). Meanwhile, cypermethrin causes knockdown effect in invertebrates by disrupting the voltage-gated sodium channels (Bloomquist and Miller, 1986; Baumler and Potter, 2007; Macoris et al., 2018). Trichlorfon interferes with the normal nerve function by inhibiting AChE enzyme located at the postsynaptic membrane (Costa et al., 2008) and insects normally show behavioural changes such as uncoordinated movement, hyperactivity and ovipositor extrusion (Alix et al., 2001; Stürmer et al., 2014). Throughout the observation, E. kamerunicus that were exposed to lower concentration of these neurotoxic insecticides displayed temporary altered mobility and muscle contraction. However, as the concentration increased, there were some $E$. kamerunicus showing constant paralysis without recovery signs, which eventually led to death (Figures 1 to 5). Thus, the application of these insecticides in oil palm plantations, especially fipronil, should be carefully managed because it may not only affect $E$. kamerunicus but other useful insects too.

Unlike neurotoxic insecticides, Bt is a pestspecific microbial insecticide used in oil palm to kill lepidopteran larvae. This bio pesticide contains crystal toxin proteins ( $\delta$-endotoxins) that binds to the gut receptor of the targeted insect and causes osmotic lysis, resulting in death of the insect (Ramlah, 2000; Ghribi et al., 2006; Norman et al., 2017). In this experiment, less than $20 \%$ weevils were killed upon treatment with $\mathrm{Bt}$ at the concentration recommended in the field (0.26\% product) (Figure 6). Our results are in line with previous studies on weevil response to $\mathrm{Bt}$ (Mohd Najib et al., 2009; 2012; Yusdayati and Hamid, 2015). Based on the International Organisation 
Biological Control (IOBC) 2005, if the mortality of the tested insect against pesticide is less than $30 \%$, the pesticide is harmless to the insect (Hassan et al., 1983; Boller et al., 2005). Thus, the use of Bt to control the population of oil palm insect pests is highly recommended.

The comparison between the type of bioassays suggests that the effect of using spray method insecticide give less detrimental impact on E. kamerunicus than oral and residual film methods. This maybe because the residual film and oral methods provide more time for E. kamerunicus to absorb/come in contact with more insecticide than the one-time contact with the spray method. This means higher amount of insecticides can enter into the insect body. Similarly, a study by Immaraju et al. (1990) showed that the citrus thrips were most sensitive to fluvalinate and dimethoate via leaf spray (residual bioassay) than using microapplicator as the thrips were repeatedly in contact with the toxicant in leaf spray method compared to receiving only one-time acute dosing in topical method. However, in the field, the combination of contact via spray and residues on plants/oil palm flowers may occur. Thus, the study results provide information regarding safe-to-use pesticides for E. kamerunicus.

There were non-significant difference of the chi-squared values in Probit analysis indicating no variation between individual weevils within a treatment, weevils are genetically the same. Besides, chi-squared values are also used to test whether the data used to estimate the median $\mathrm{LC}\left(\mathrm{LC}_{50}\right)$ fit to the Probit model or not (Robertson et al., 2007). If the chi-squared values are significantly different at $p=$ 0.05 , then the data does not fit with the model. Thus, other models that fit to the data should be used.

The regression slope indicates the degree of homogeneity of a population on its response to the toxicant. According to Schouest and Miller (1988), steeper slope indicates a population is more homogenous (i.e. have similar age) or has higher consistency in terms of exposure to chemical substance. The slope also shows the degree of sensitivity of insect to a toxicant. Steeper slope indicates that insect is more sensitive to the toxicant.

In this study, the regression slope of male weevils is steeper than female, this demonstrates male weevils are more sensitive to the insecticides than the females. Besides, the steeper slope from the fipronil treatment shows that weevils are more sensitive to fipronil than cypermethrin and trichlorfon. However, when the slopes between methods for each insecticide were compared, it was found that weevils were more sensitive to trichlorfon treated orally but they were more sensitive to fipronil in spray application. Weevil has similar sensitivity towards cypermethrin regardless of bioassay methods.

\section{CONCLUSION}

The use of insecticide is one of the effective ways to control insect pests in oil palm plantation especially during pest outbreak but it may affect oil palm pollinator as well. Our findings demonstrated that fipronil exhibits the strongest insecticidal effect on E. kamerunicus under laboratory condition. Although the lethality of cypermethrin, trichlorfon and $\mathrm{Bt}$ is lower than fipronil, the side effect of these chemicals should not be neglected. Hence, the sublethal tests (i.e. the effect of insecticide on insect biology, physiology and behaviour) on insect should be carried out to find out the impact of insecticide on other insects especially the insect natural enemies. The bioassay data in the laboratory should be compared with the actual field data so that it could tell us which bioassay techniques could reflect the real effect of insecticides in the actual environment where the insect come in contact with direct spray, plant residues or food contaminated with insecticides. Therefore, semi-field (field cage) and field tests should also be conducted to better determine the toxicity of insecticides on weevils under the actual environment.

\section{REREFENCE}

Abbott, W S (1925). A method of computing the effectiveness of an insecticide. J. Economic Entomology, 18: 265-267.

Abdelrahmen, I (1973). Toxicity of malathion to the natural enemies of California red scale, Aonidiella aurantii (Mask.). Aust. J. Agric. Res., 24: 119-133.

Alix, A; Cortesero, A M; Nenon, J P and Anger, J P (2001). Selectivity assessment of chlorfenvinphos reevaluated by including physiological and behavioral effects on an important beneficial insect. Environmental Toxicology and Chemistry, 20(11): 25302536.

Basri, M W; Halim, A H and Hitam, A H (1983). Current status of Elaeidobius kamerunicus Faust and its effects on oil palm industry in Malaysia. PORIM Occasional Paper, 6: 39.

Basri, M W; Masijan, Z; Halim, A H and Tayeb, D $M$ (1987). The population census and the pollinating efficiency of the weevil, Elaeidobius kamerunicus in Malaysia - A status report, 1883-1986. Proc. of the 1987 International Oil Palm/ Palm Oil Conferences: Progress and Prospect. p. 535-549.

Basiron, Y (2007). Palm oil production through sustainable plantations. Eur. J. Lipid Sci. Technol., 109: 289-295. 
Baumler, R E and Potter, D A (2007). Knockdown, residual, and antifeedant activity of pyrethroids and home landscape bioinsecticides against Japanese beetles (Coleoptera: Scarabaeidae) on Linden foliage. J. Economic Entomology, 100: 451-458.

BEPI (2018). Statistic oil extract rate. http:// bepi.mpob.gov.my / index.php / en / statistics / oilextraction-rate.html, accessed on 5 March 2018.

Bloomquist, J R and Miller, T A (1986). Sodium channel neurotoxins as probes of the knockdown resistance mechanism. Neurotoxicology, 7: 217-224.

Boller, E F; Vogt, H; Ternes, P and Malavolt, C (2005). Working Document on Selectivity of Pesticides (2005). https://www.iobc-wprs.org/ ip_ipm/archive/03021_IOBC_WorkingDocument Pesticides_Explanations.pdf, accessed in December 2017.

Brooks, T G (2010). Chapter 96: Interactions with the gamma-aminobutyric acid A-receptor: Polychlorocycloalkanes and recent congener and other ligands. Hayes' Handbook of Pesticide Toxicology (Krieger, R ed.). Academic Press, USA. p. 2065-2091.

Carrillo, D; Crane, J H and Peña, J E (2013). Potential of contact insecticides to control Xyleborus glabratus (Coleoptera: Curculionidae), a vector of Laurel Wilt disease in avocados. J. Economic Entomology, 106(6): 2286-2295.

Chandra, M; Raj, J; Dogra, T D; Rajvanshi, A C and Raina, A (2014). Determination of median lethal dose of triazophos with DMSO in winstar rats. Asian J. Pharmaceutical and Clinical Research, 7(4): 64-67.

Chiu, S B (1984). Some Aspects of the Ecology of the Elaeidobius kamerunicus Faust, the Pollinating Weevil of Oil Palm with Emphasis on Developing Sampling Techniques. M.Sc. thesis. Universiti Pertanian Malaysia, Serdang, Selangor, Malaysia. p. 1-2.

Chung, G F (1989). Spraying and trunk injection of oil palm for pest control. The Planter, 65(764): 500-524.

Cole, L M; Nicholson, R A and Casida, J E (1993). Action of phenylpyrazole insecticides at the GABAgated chloride channel. Pesticide, Biochemistry and Physiology, 46: 47-54.

Costa, L G; Giordano, G; Guizzetti, M and Vitalone, A (2008). Neurotoxicity of pesticides: A brief review. Frontiers in Bioscience, 13: 1240-1249.

De Lame, F M; Hong, J J; Shearer, P W and Brattsten, L B (2001). Sex-related differences in the tolerance of oriental fruit moth (Grapholita molesta) to organophosphate insecticides. Pest Management Science, 57: 827-832.

Desneux, N; Denoyelle, R and Kaiser, L (2006). A multi-step bioassay to assess the effect of the deltamethrin on the parasitic wasp Aphidius ervi. Chemosphere, 65: 1697-1706.

Donough, C R; Chew, K W and Law, I H (1996). Effect of fruit set on OER and KER: Results from studies at Pamol Estates (Sabah) Sdn Bhd. The Planter, 72: 203219.

Ferdous Alam, A S A; Er, A C and Halimah Begum (2015). Malaysian oil palm industry: Prospect and problem. J. Food Agricultural and Environment, 13(2): 143-148.

Ghribi, D; Zouari, N; Hassen, T and Jaoula, S (2006). Improvement of Bacillus thuringiensis delta-endotoxin production by overcoming carbon catabolite repression through adequate control of aeration. Enzyme and Microbial Technology, 40: 614-622.

Greathead, D J (1983). The multimillion dollar weevil that pollinates the oil palms. Antenna (Royal Entomological Society of London), 7: 105-107.

Gupta, R C and Milatovic, D (2014). Chapter 23: Insecticides. Biomarkers in Toxicology (Gupta, R C ed.). Academic Press, USA. p. 389-407.

Hassan, S A; Bigler, F; Bogenschütz, H; Brown, J U; Firth, S I; Huang, P; Ledieu, M S; Naton, E; Oomen, P A; Overmeer, W P J; Rieckmann, W; Samsoe-Petersen, L; Viggiani, G and Zon, A Q Van (1983). Results of the second joint pesticide testing programme by the IOBC/WPRS working group pesticides and beneficial arthropods. Z. Angew. Entomol., 95: 151-158.

Hussein, M Y and Rahman, W H A (1991). Life tables for Elaeidobius kamerunicus Faust (Coleoptera: Curculionidae) in oil palm. The Planter, 67: 3-8.

Immaraju, J A; Morse, J G and Brawner, O L (1990). Evaluation of three bioassay techniques for citrus thrips resistance and correlation of the leaf dip method to field mortality. J. Agric. Entomolo., 7(1): 1727.

Kaakeh, W (2006). Toxicity of imidacloprid to developmental stages of Rhynchophorus ferrugineus (Curculionidae: Coleoptera): Laboratory and field test. Crop Protection, 25: 432-439.

Kalidas, P; Rajasekhar, P and Lalitha, S V L (2008). Impact of pesticides on the pollinating weevils of oil palm. J. Plantation Crops (Short Scientific Report), 36(3): 460-462. 
Kevan, P G; Hussein, N Y; Hussey, N and Wahid, M B (1986). Modelling the use of Elaeidobius kamerunicus for pollination of oil palm. The Planter, 62: 89-99.

Kok, C C; Eng, O K; Abdul Rahman Razak; Marcon, P G and Loong, L M (2010). Chlorantraniliprole: A novel insecticide for bagworm (Metisa plana) control in oil palm plantation. The Planter, 86(1009): 223-235.

Kok, C C; Eng, O K; Abdul Rahman Razak; Adzemi Mat Arshad and Marcon, P G (2012). Susceptibility of bagworm Metisa plana (Lepidoptera: Psychidae) to chlorantraniliprole. Pertanika J. Tropical Agricultural Science, 35(1): 149-163.

Kuntom, A; Ai, T Y; Norman, K and Beng, Y C (2007). Pesticide application in the oil palm plantation. Oil Palm Bulletin No. 54: 52-67.

Kushairi, A (2019). Malaysian oil palm industry Performance 2018 and prospects for 2019. Palm Oil Economic Review \& Outlook (R\&O) Seminar 2019 Palm Oil Driving Economic Sustenance. Le Meridien Putrajaya, Malaysia. p. 3.

Lawton, D M (1982). Pollination and fruit set in oil palm (Elaeis guineensis Jacq.). International Conference on Oil Palm in Agriculture in the Eighties. p. 241-262.

Macoris, M DL; Martins, A J; Andrighetti, M T M; Lima, J B P and Valle, D (2018). Pyrethroid resistance persists after ten years without usage against Aedes aegypti in governmental campaigns: Lessons from São Paulo State, Brazil. PLOS Neglected Tropical Diseases, 12(3): e0006390.

Martínez, L C; Hurtado, R E; Araque, L and Rincón, V (2009). Avances de la campaña regional para el manejo de la información de insectos defoliadores en la zona central. Palmas, 30: 51-61.

Mohd Najib, A; Ramlah, A A S; Mohamed Mazmira, M M and Basri, M W (2012). Effect of Bt products, Lepcon-1, Bagfog-1(S) and Ecobac-1(EC), against the oil palm pollinating weevil, Elaeidobius Kamerunicus and beneficial insects associated with Cassia cobanensis. J. Oil Palm Res. Vol. 24: 1442-1447.

Mohd Najib, A; Ramlah, S A A; Mohamed Mazmira, M M and Basri, M W (2009). Effect of Bacillus thuringiensis, Terakil-1R and Teracon-1R against oil palm pollinator, Elaeidobius kamerunicus, and beneficial insects associated with Cassia cobanensis. J. Oil Palm Res. Vol. 21: 667-674.

Munson, S C and Gottlieb, M I (1953). The differences between male and female American roaches in total lipid content and in susceptibility to DDT. J. Economic Entomology, 46(5): 798-802.
Noor Farehan, I; Syarafina, R and Idris, A B (2013). Toxicity of three insecticides on the predator of oil palm leaf-eater pests, Sycanus dichotomus Stal. (Hemiptera: Reduviidae). Academic J. Entomology, 6(1): 11-19.

Norman, K (1994). Control of some insect pests of oil palm (Elaeis guineensis). Paper presented during a student Seminar in Pesticides Application Course at Silwood Park, Imperial College, United Kingdom.

Norman, K and Basri, M W (1992). A survey of current status and control of nettle caterpillars (Lepidoptera: Limacodidae) in Malaysia (19811990). PORIM Occassional Paper No. 27: 22 pp.

Norman, K; Ramlah, S A A; Ramle Moslim; Zulkefli Masijan and Mohd Basri Wahid (2017). Integrated pest management in oil palm plantations in Malaysia. Integrated Pest Management in Tropical Regions (Rapisarda, C and Cocuzza, G E M eds.). CABI, UK. p. 270-284.

Paramasivam, M and Selvi, C (2017). Laboratory bioassay methods to assess the insecticide toxicity against insect pests - A review. J. Entomology and Zoology Studies, 5(3): 1441-1445.

Poinar, G O Jr; Jackson, T A; Bell, N L and Basri, M W (2002). Elaeolenchus parthenonema n. g., n. sp. (Nematoda: Sphaerularioidea: Anandranematidae n. fam.) parasitic in the palm pollinating weevil Elaeidobius kamerunicus Faust, with a phylogenetic synopsis of the Sphaerularioidea Lubbock, 1861. Systematic Parasitology, 52: 219-225.

Ponnamma, K N; Sajeebkhan, A and Vijayan, A (2006). Adverse factors affecting the population of pollinating weevil, Elaeidobius kamerunicus F. and fruit set on oil palm in India. The Planter, 82: 555557.

Prasetyo, A E; Lopez, J A; Eldridge, J R; Zommick, D H and Susanto, A (2018). Long-term study of Bacillus thuringiensis application to control Tirathaba rufivena, along with the impact to Elaeidobius kamerunicus, insect biodiversity and oil palm productivity. J. Oil Palm Res. Vol. 30(1): 71-82.

Ramlah, S A A (2000). Mechanism of Action of Bacillus thuringiensis $\delta$-Endotoxins: Binding Studies of $\delta$-endotoxins to Brush Border Membrane Vesicle of Metisa plana (Walker). Ph.D thesis. Universiti Kebangsaan Malaysia. 216 pp.

Rao, V and Law, I (1998). The problem of poor fruit set in parts of East Malaysia. The Planter, 74(870): 463-483. 
Rathman, R J; Johnson, M W; Rosenheim, J A; Tabashnik, B E and Purcell, M (1992). Sexual differences in insecticide susceptibility and synergism with piperonyl butoxide in the leafminer parasitoid Diglyphus begini (Hymenoptera: Eulophidae). J. Economic Entomology, 851(1): 15-20.

Robertson, J L; Russel, R M; Preisler, H K and Savin, N E (2007). Bioassay with Arthropods. Second edition. CRC Press, Boco Raton, USA. 199 pp.

Rosma Hasibuan; Gede Swibawa, I; Agus M Hariri; Sudi Pramono; Susilo, F X and Nurafiah Karmike (2002). Dampak aplikasi insektisida permetrin terhadap serangga hama (Thosea sp.) dan serangga penyerbuk (Elaeidobius kamerunicus) dalam agroekosistem kelapa sawit. Jurnal Hama dan Penyakit Tumbuhan Tropika, 2(2): 42-46.

Roy, S and Prasad, A K M (2018). Sex-based variation in insecticide susceptibility and tolerance related biochemical parameters in tea mosquito bug Helopeltis theivora. Phytoparasitica, 46(3): 405-410.

Roundtable on Sustainable Palm oil (RSPO) (2013). Principle and Criteria for the Production on Sustainable Palm Oil. file:///C:/Users/User/Downloads/ RSPO $\% 20$ Principles $\% 20 \& \% 20$ Criteria $\% 20$ 2013-English.pdf, accessed on 11 July 2018. 53 pp.

Schouest, Jr L P and Miller, T A (1988). Factors influencing pyrethroid toxicity in pink bollworm (Lepidoptera: Gelechiidae): Implication for resistant management. J. Economic Entomology, 81(2): 431-436.

Scott, J G and Rutz, D A (1988). Comparative toxicities of seven insecticides to house flies (Diptera: Muscidae) and Urolepis rufipes (Ashmead) (Hymenoptera: Pteromalidae). J. Economic Entomology, 81(3): 804-807.

Shearer, P W and Usmani, K A (2001). Sex-related response to organophosphorus and carbamate insecticides in adult oriental fruit moth, Grapholita molesta. Pest Management Science, 57: 822-826.

Stürmer, G D; De Freitas, T C; Heberlem, M D E A; De Assis, D R; Vinadé, L; Pereira, A B; Franco, J L and Dal Belo, C A (2014). Modulation of dopaminergic neurotransmission induced by sublethal doses of the organophosphate trichlorfon in cockroaches. Ecotoxicology and Environmental Safety, 109: 56-62.

Sugih, W; Heru, S; Achmad, F and Thiagarajan, S (1996). Influence of rainfall, palm age and assisted pollination on oil palm fruitset in Riau, Indonesia. International Palm Oil Congress: Competitiveness for the $21^{\text {st }}$ Century - Agriculture Conference. p. 207-220.
Syed, R A (1979). Studies of oil palm pollination by insects. Bulletin of Entomological Research, 69: 213-224.

Syed, R A; Law, I H and Corley, R H V (1982). Insect pollination of oil palm: Introduction, establishment and pollinating efficiency of Elaeidobius kamerunicus Faust. The Planter, 58: 547-561.

Syed, R A and Saleh, A (1988). Population of Elaeidobius kamerunicus Fst. in relation to fruit set. Proc. of the 1987 International Oil Palm Conference Progress and Prospects. p. 528-534.

Telfer, W H (2009). Chapter 264: Vitellogenesis. Encyclopaedia of Insects. Second edition (Resh, V H and Cardé, R T eds.). Academic Press, USA. p. 10411043.

Terriere, L C (1982). The Biochemistry and Toxicology of Insecticide. Corvallis: Oregon State University. 296 pp.

Tillman, P G (1995). Susceptibility of Microplitis croceipes and Cardiochiles nigriceps (Hymenoptera: Braconidae) to field rates of selected cotton insecticides. J. Entomological Science, 30: 390-396.

Valle, D (1993). Vitellogenesis in insects and other groups - A review. Mem. Inst. Oswaldo Cruz, Rio de Janeiro, 88(1): 1-26.

Wahyu Syahputra; Tobing, M C; Lisnawati and Prasetyo, A E (2018). The influence of several insecticides on Elaeidobius kamerunicus (Coleoptera: Curculionidae) population in Kalianta Oil Palm Plantation, Riau. J. Agroekoteknology, 6(3): 626633.

Weaver, D K; Wells, C D; Dunkel, F V; Bertsch, W; Sing, S E and Sriharan, S (1994). Insecticidal activity of floral, foliar, and root extracts of Tagetes minuta (Asterales: Asteraceae) against adult Mexican bean weevils (Coleoptera: Bruchidae). J. Economic Entomology, 87(6): 1718-1725.

Wood, B J (1986). Pest of Oil Palms in Malaysia and their Control. Kuala Lumpur: Incorporated Society of Planters. 204 pp.

Young, S N (1971). Some pests of oil palm on the east coast of Sabah. Crop Protection in Malaysia (Wastie, $\mathrm{R}$ L and Wood, B J eds.). The Incorporated Society of Planters, Kuala Lumpur. p. 107-115.

Yusdayati, R and Hamid, N H (2015). Effect of several insecticide against oil palm pollinator's weevil, Elaeidobius kamerunicus (Coleoptera: Curculionidae). Serangga, 20(2): 27-35. 